\section{SIR VICTOR HORSLEY, F.R.S.}

SIR VICTOR A. H. HORSLEY, whose death $S$ on July 16 we record with the deepest regret, was born in 1857 of a family long distinguished for ability in natural science and the arts. His descent was chosen by Gaiton to illustrate the view that unusual talents are hereditary in certain stocks of the community in this island.

On leaving school he entered University College, and carried all before him. He early showed his interest in the physiology of the nervous system, and in I884 published a study, with Prof. Schäfer, on the functions of the marginal convolution. The same year, at the early age of twenty-seven, he was appointed professor-superintendent of the Brown Institution, a post much coveted by physiologists. His energy and enthusiasm, coupled with his astonishing youth, were a revelation to all who came into contact with him. In his company work became a fascinating game, and never was there such a keen playmate. He was singularly attractive, with a charming voice and infectious laugh; his manner was boyishly unaffected, and as he struck out one line after another in the application of physiology to medicine our enthusiasm was unbounded. He was always sincerely interested in the work of others, and would devote much time and energy to understanding it thoroughly. Throughout his period at the Brown Institution he worked more particularly at hydrophobia, and the functions of the thyroid and pituitary body, besides continuing his studies in cerebral localisation.

Horsley was surgeon to University College Hospital and to the National Hospital for the Paralysed and Epileptic, Queen Square, W.C., and it was at this time that he became the pioneer of surgery of the central nervous system. Instigated by Dr. Hughlings Jackson and Sir William Gowers, he was the first successfully to operate on the brain and to remove a tumour pressing on the spinal cord. To us his operating was an inspiration; he was never at a loss, and his brilliancy lay rather in his attitude to the problem in front of him than in pure mechanical dexterity. He was never afraid, and the complete reliance he placed on his subordinates was sometimes almost embarrassing.

Honours poured upon him. $\mathrm{He}$ was early elected a Fellow of the Royal Society, and obtained the Royal medal; Halle made him an M.D., Paris elected him a Fellow of the Académie de Médecine, and numerous medical societies all over the world claimed him as an honorary member. No British worker in his field has been so much admired on the Continent as Horsley.

Practice came to him abundantly, but until shortly before the war he always devoted one day in the week to work in his private laboratory, tucked away under the lecture theatre at University College. Here he did all his work on the functions of the brain, including the long series of researches with Dr. R. H. Clarke on the cerebellum, carried out with an accuracy never before attainable. Many younger men who are now distinguished as neurologists in different parts of the world came to work with him here in London, and owe the success of their researches not only to his guidance, but to his remarkable operative skill on animals, for in almost all cases the actual experimental lesions were his handiwork.

He was Croonian lecturer to the Royal Society, and on this occasion published the work carried out with his brother-in-law, Prof. Gotch, on electrical changes in the spinal cord.

He was, however, essentially a pioneer, interested mainly in working at a subject until the field was laid open to all. This accounts for the comparatively small bulk of his publications. $\mathrm{He}$ showed all the surgeons of the world how to operate on the brain and spinal cord, but left no co-ordinated account of his methods, procedure, or results. This was in part due to impatience at being forced to go back over the road he had travelled, and partly to the overwhelming worries of the political and social work into which he threw himself with all his original scientific ardour.

His death was characteristic of his desire always to be moving forwards, to be in the advance, for, as consulting surgeon and inspector of hospitals, he might have stopped in the Mediterranean, where he had been occupied usefully for some time. But he demanded to be sent to Mesopotamia, where he knew the need was urgent, and there he died at Amara, laying down his life at the early age of fifty-nine.

H. H.

\section{NOTES.}

ThE death of Sir William Ramsay on July 23 has deprived the world of one of its greatest men and science of a pioneer whose work has opened up the richest fields of research explored in modern times. For several months the sympathies of scientific men have been with Sir William on his bed of affliction, and rebellious thoughts have surged through the minds of all of us that such an intellectual giant should have been rendered helpless when his dominating influence was most needed in national life. Though he was sixty-three years of age, he was much younger in spirit and vigour; and until last November everyone who knew him supposed that he had a long period of activity still in front of him. He has now passed to his rest, and no words can express the grief felt by his countless friends and admirers at the loss sustained by them and by the nation. His genius was undoubted, and in personal characteristics, as well as in productive work, he represented science at its highest and best. His funeral is taking place at Hazlemere Church, High Wycombe, as we go to press, but the place where his remains should rest is Westminster Abbey, for the honour which he brought to his country would have been justly recognised by this mark of national recognition. The greatness of his work, and the high regard in which it is held, were shown in an article on Sir William Ramsay in our series of "Scientific Worthies" in NatuRe of January II, Ig12. His memory will be cherished with affection by all who came under the influence of his attractive personality, and his contributions to knowledge will constitute a permanent monument to him in the fields of science. The nation itself has been exalted by his achievements, and a memorial of them should be placed where all may see and be uplifted by the spirit of scientific life so fully manifested in him. No. 2439, vOL. 97] 